\title{
Productivity of rock reinforcement: methodology development
}

\author{
by A. Gustafson*, H. Schunnesson*, M. Timusk ${ }^{\dagger}$, and \\ R. Hauta ${ }^{\dagger}$
}

\section{Synopsis}

The working environment for ground support installation in mines has improved during the last 20-30 years, with more mechanized equipment for installation of ground support elements such as bolts, cable bolts, and screens. Ground support installation productivity has, however, not followed the same development curve, remaining more or less constant. In some cases, for example the mechanized installation of bolts, productivity has even dropped. One reason for this is that modern mechanized bolt rigs are complex. In this paper we evaluate manual and mechanized ground support systems, propose a way to measure the productivity of bolt rigs, and make relevant comparisons between different mines and equipment. Some productivity measures for rock reinforcement are suggested, using productivity results from eight case study mines.

\section{Keywords}

rock reinforcement, bolting, productivity measures, mechanization, underground mining. mechanized bolting, as this improves operator safety and arguably boosts net capacity. Internationally, however, manual installation of bolts remains common, with some claiming that manual installation is more productive (Bawden, 2011).

Figure 1 presents two fundamentally different procedures for rock reinforcement. A fleet utilization situation allows reinforcement of larger areas, longer drifts, or locations close to each other where the waiting and transportation time is negligible. In these situations, there is no shortage of work faces, and the machine can work more or less continuously, moving from one face to the next. Here, the overall rig utilization basically depends on the rig availability. In the pit-stop or single face scenario, the rock support is part of a cyclic work process where each subactivity, including rock reinforcement, has to be performed as quickly as possible before the next activity can start. Between these subactivities, the equipment is idle, and support activities can be performed e.g. maintenance, to ensure the rig is fully operational when needed. Here, availability and utilization will differ significantly. In addition, the net bolt installation capacity is very important, while the consumables logistics are negligible. In most real mining situations, the rock reinforcement process is a mixture of both types. Therefore, the selected productivity measure must, to some extent, include both.
* Division of Mining and Geotechnical Engineering, Lulea University of Technology, Lulea.

+ Division of Engineering, Laurentian University, Sudbury, Canada.

(c) The Southern African Institute of Mining and Metallurgy, 2016. ISSN 2225-6253. Paper received oct. 2015; revised paper received Jan. 2016. 


\section{Productivity of rock reinforcement: methodology development}

\section{OPTIMISE MACHINE OR FACE?}

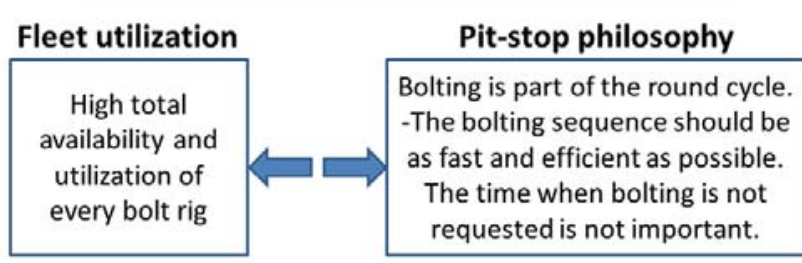

Figure 1 - Different views of rock reinforcement productivity

Previous research has focused on the performance of rockbolts and the application of numerical modelling for ground support problems (Jalifar, Aziz, and Hadi, 2004), increased productivity through improved rock support practices (Morland and Thompson, 1985), the contribution of bolting intensity and installation efficiency to roof behaviour and stability (Clarc and Filipowski, 1984), and the effectiveness of rockbolts in providing rock support considering the time the area is left without support (Raffoux and Dejean, 1980). To the best of the authors' knowledge, researchers have not compared measures from different support systems under different conditions in different mines.

A challenge for productivity measures of bolting and screening procedures is how to measure productivity in a structured but also relevant way. In this paper we suggest a way of comparing the productivity of different ground support systems used in different mines, even if the prerequisites, such as blasting practices, drift irregularities, rock stresses, human factors, maintenance strategy, working conditions, etc., differ, using data mining (production and maintenance data), interviews, site visits, and time studies (in Canada only). The results are based on data from eight case study mines situated in the Nordic countries and Canada, and on the rock support techniques used in these mines. The various mines' support systems and bolting equipment are described and analysed, and a method suggested to measure productivity in a uniform way, allowing the comparison of the productivity of different operations and equipment across mines. Finally, the productivity associated with the support elements and installation procedures of the eight mines is analysed. The project is part of the Rock Tech Centre (RTC) project 'Mining Initiative on Ground Support Systems and Equipment' (MIGS II).

\section{Equipment for rock support}

\section{Rock support elements}

Bolt installation consists of three separate activities: hole drilling, insertion of grouting substances, and installation of the bolt. Many support elements are available on the market. This study is limited to the types used by the participating mines; the relevant bolts and screens are as follows.
- Mechanically anchored rockbolts-Mechanically anchored rockbolts are commonly used as rock reinforcement in underground mines (Hoek and Wood, 1987). There are two types of mechanisms for mechanically anchored bolts:

- The bolt is tensioned to expand at the end to reach its load-bearing capacity

- The bolt is tensioned to get a mechanical interlock at the end but the void between the bolt and borehole wall is filled by grout to resist the corrosive environment.

As mechanically anchored rockbolts provide reliable anchorage in good rock, high bolt loads can be achieved; however, correct installation requires a skilled operator (Hoek and Wood, 1987)

- Friction-anchored rockbolt - Swellex-The Swellex is a type of friction-anchored rockbolt where anchorage is provided by the friction between the surface of the bolt and the wall of the borehole. The Swellex is a frictional tube that also must achieve mechanical interlocking ( $\mathrm{Li}$ and Håkansson, 1999). Installation is fast and simple, and the bolt gives immediate support after installation (Hoek and Wood, 1987). Its lifetime could be decreased by corrosion, but various types of corrosion protection, such as plastic coating, can neutralize the corrosion problem

> Friction-anchored rockbolt - Splitset-The Splitset, another type of friction-anchored rockbolt, consists of a slotted hollow strength steel tube and faceplate (Bawden, 2011). The Splitsets are installed into an undersized hole; after being inserted, they are affixed by the radial spring force generated by compression. This provides frictional anchorage along the full length of the tube. This type of rockbolt can be particularly useful in mild rockburst conditions, as the bolt may slip but will not break (Bawden, 2011). Generally speaking, it is useful for short-term duties in the mining industry (Hoek and Wood, 1987). The Splitset has a high deformation capacity (Li, 2010) and can be installed quickly (Hoek and Wood, 1987), but it cannot manage heavy loads (Atlas Copco, 2015). In addition, it can become corroded under high groundwater conditions (Hoek and Wood, 1987) 


\section{Productivity of rock reinforcement: methodology development}

- Resin-grouted bolts-In this type of rockbolt, resin and a catalyst are put into small plastic bags and inserted into the borehole. When the bolt is pushed through the hole, it breaks the plastic bag, covering the bolt with resin and catalyst. In this way, very strong anchors can be set into rock of poor quality (Hoek and Wood, 1987). However, resins are expensive and can have a limited shelf life, particularly in hot climates (Hoek and Wood, 1987)

> Cement-grouted bolts-Here, cement grout is used to encapsulate the rockbolt with the wall of the borehole. There are three stages to this method: drilling the borehole; injecting cement grout; pushing the bolt through the borehole. Cement-grouted rebars have a high load-bearing capacity but a low deformation capacity (Li, 2007). These bolts can be used at shallow depths where in situ stresses are low and the main risk comes from gravitational rockfalls; in other words, when the strength of the bolt is more important than its deformation capacity. At depths where in situ stresses are high, however, it is no longer appropriate to use rebar bolts as rock reinforcement devices ( $\mathrm{Li}$, 2007)

> Welded wire mesh-The screen installation used in the case study mines requires sheets of welded wire mesh (Figure 2), which is inexpensive and has a large loadbearing capacity (Bawden, 2011). A very efficient way of installing mesh with a mechanical rig is to use a separate screen arm to lift the screen into place and then use the bolt arm to fix the screen to the rock surface. The load and displacement capacity of mesh depend on the type of metal and size of the wire and dictate the load capacity of the wire and weld (Bawden, 2011).

\section{Available techniques and procedures}

Between them, the case study mines use four bolt rig suppliers. The mechanization level of the rigs varies from manual to mechanized installation of bolts. In the Nordic countries, safety concerns have forced the development of fully mechanized bolt rigs, with the operator protected in the cabin during bolt and screen installation. Today, this type of equipment is dominant in the Nordic mines. In North America, the situation is more complex. The main argument for manual installation of bolts in the studied Canadian mines is that it is assumed to be more efficient, with higher productivity. In addition, the Canadian mines have a strong tradition of using manual bolters.

Productivity issues are important if technology is to be changed. Although the argument that manual installation is faster is widespread, this claim was not substantiated by the present work. Moreover, automation has advantages other than speed. For example, precision of installation will increase with mechanized rigs if they are navigated.

Throughout this research, the authors held discussions with the case study mining companies and suppliers of the rigs on the merits of mechanized versus manual bolting. Findings were split. On the one hand, automation is extremely important to both deep mining and safety. On the other hand, manual operations offer greater flexibility, something that cannot be ignored when selecting equipment.

\section{Research methodology}

This study considered eight mines, belonging to four different companies in Sweden and Canada. Data was collected during site visits before being processed and analysed. In-depth interviews were conducted with mining personnel, including operators of the bolt rigs, managers, and maintenance personnel. For the manual rigs, a time study was performed to determine all relevant activities and their corresponding times. For the mechanized rigs, International Rock Excavation Data Exchange Standard (IREDES) files were collected and analysed, along with production and maintenance data.

A definition of productivity for bolt installation was developed by combining the various types of information obtained from data records, time studies, and interviews. The definition was validated and improved during discussions with the mining companies and equipment suppliers. After that, the suggested definition of productivity for bolt rigs was tested on the respective mines for productivity comparisons. A schema of the research methodology is shown in Figure 3.

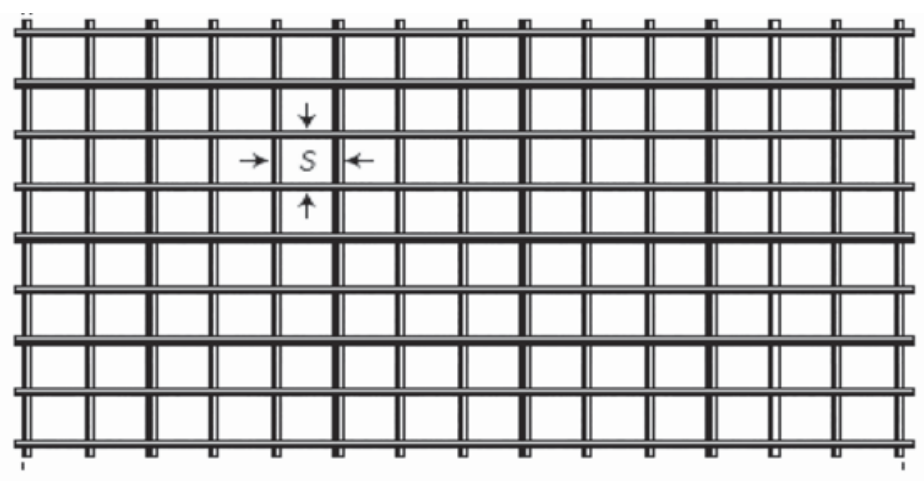

Figure 2-Welded wire mesh (Bawden, 2011) 


\section{Productivity of rock reinforcement: methodology development}

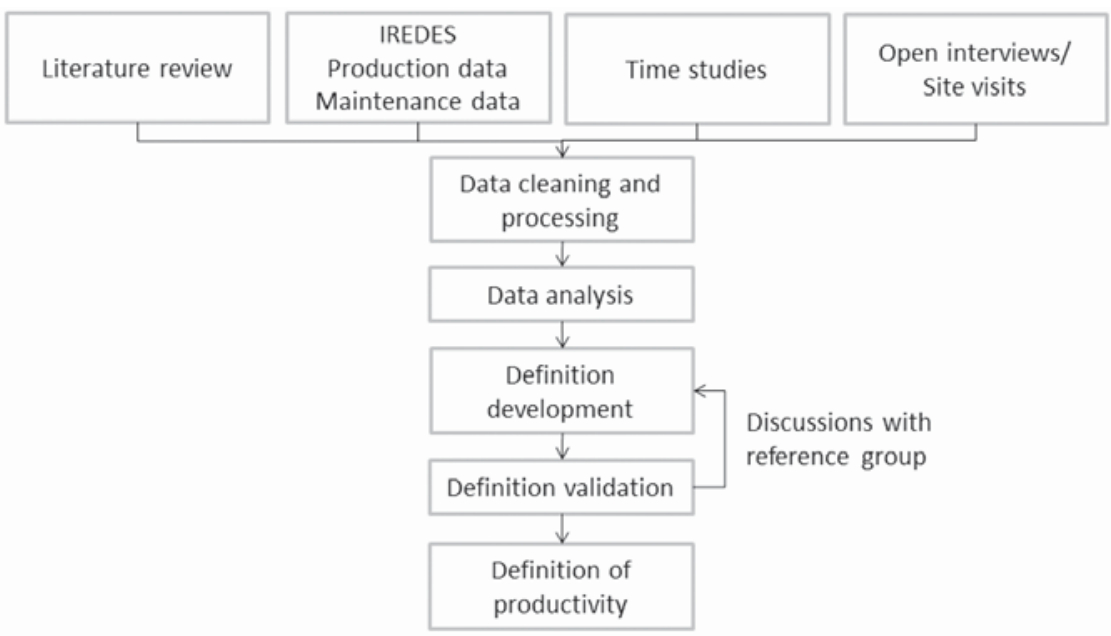

Figure 3-Research methodology

Table I

Mining method and rock quality of the case study mines

\begin{tabular}{|l|c|c|c|}
\hline Mine & Mining method & Backfill & Rock quality \\
\hline Mine 1 & Cut and fill & Processing sand & Weak rock conditions \\
\hline Mine 2 & Cut and fill & Waste rock & Good; hardness reaches occasionally extreme values (550 Mpa) \\
\hline Mine 3 & $\begin{array}{c}\text { Sublevel stoping, rill mining, } \\
\text { and cut and fill }\end{array}$ & Paste and rock fill & Varying from reasonably good to weak \\
\hline Mine 4 & Sublevel caving & & Varying rock conditions and seismically active zones \\
\hline Mine 5 & Sublevel caving & & Wallrock moderate to high compressive strength. Ore low to moderate strength \\
\hline Mine 6 & VRM/slot and slash bulk mining & & Wallrock moderate to high compressive strength. Ore low to moderate strength \\
\hline Mine 7 & Cut and fill & Rock backfill and cement & Fair to very poor rock \\
\hline Mine 8 & Sublevel stoping & \\
\hline
\end{tabular}

The ground support productivity was calculated using the following expressions:

$$
\begin{aligned}
& \text { Total time at the face }(\%)=\frac{\text { Long term utilisation }}{\text { Work capacity }} \\
& \text { Total time bolting }(\%)=\frac{\text { Long term utilisation }}{\text { Net cycle time }} \\
& \text { Face efficiency }(\%)=\frac{\text { Total time bolting }(\%)}{\text { Total time at the face }(\%)}
\end{aligned}
$$

\section{Field studies}

Table I gives an overview of the eight mines, including their mining methods and backfill, as well as the quality of the rock.

As noted, the eight mines use four different suppliers (suppliers A-D, see Table II) of bolt rigs. The level of mechanization differs from semi-mechanized drilling and bolting to manual drilling and bolting. One type of rig (supplier D) performs only manual bolting, with drilling performed by another rig. Table II provides an overview of the various support systems and the level of mechanization of the equipment used for bolt installation.

Several different types of data (IREDES, production and maintenance data, data from time studies) were collected and analysed. Table III presents data on the number of bolts installed per year, bolt length, number of shifts per week, and hours per shift for the case study mines where data could be collected. To generate a relevant comparison of the productivity of the mines, it is important to take this data into account.

\section{Definition of productivity}

Common productivity definitions must be used to simplify the evaluation and benchmarking of bolting operations. In the past, the absence of such definitions has led to confusion when comparing operations across mining companies. For example, mixing work capacity with long-term capacity can lead to confusion about the performance level at different 


\section{Productivity of rock reinforcement: methodology development}

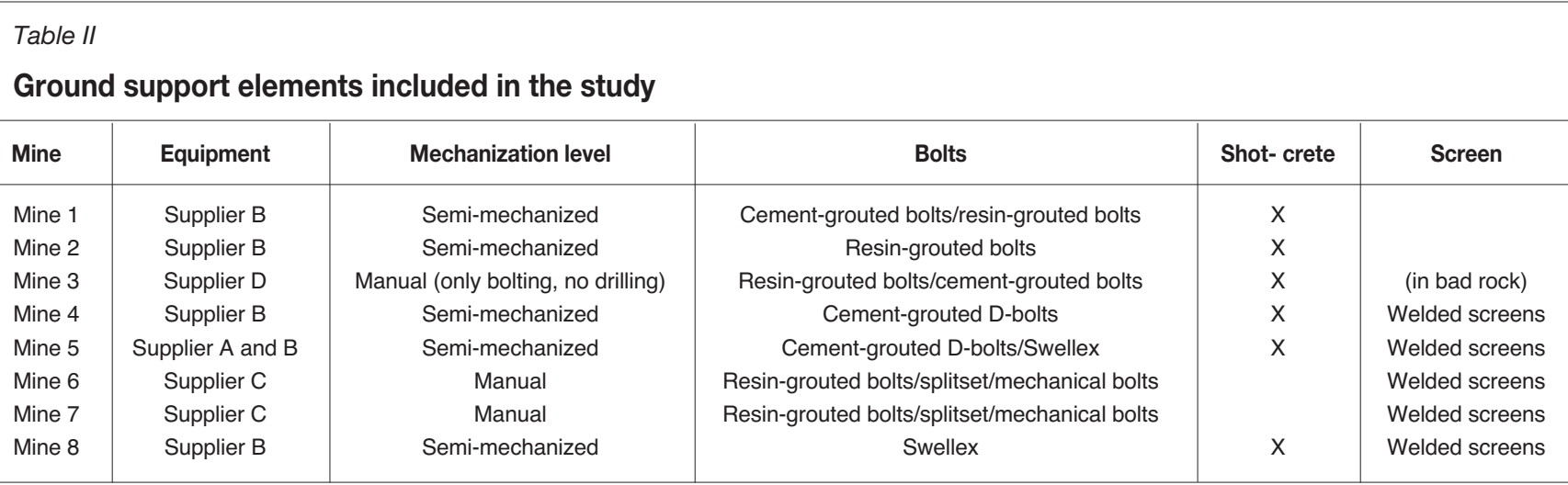

Table III

General information on the mines included in the study

\begin{tabular}{|c|c|c|c|c|c|c|c|}
\hline & $\begin{array}{c}\text { Expanding friction } \\
\text { bolts (Swellex) } \\
\text { Mine } 8\end{array}$ & $\begin{array}{c}\text { Resin-grouted } \\
\text { bolts } \\
\text { Mine } 3\end{array}$ & $\begin{array}{c}\text { Cement-grouted } \\
\text { bolts } \\
\text { Mine } 1\end{array}$ & $\begin{array}{c}\text { Resin-grouted } \\
\text { bolts } \\
\text { Mine } 6\end{array}$ & $\begin{array}{c}\text { Resin-grouted } \\
\text { bolts } \\
\text { Mine } 7\end{array}$ & $\begin{array}{l}\text { Cement-grouted } \\
\text { bolts } \\
\text { Mine } 5 \text { (in-house) }\end{array}$ & $\begin{array}{c}\text { Cement-grouted } \\
\text { bolts } \\
\text { Mine } 5 \text { (contractor) }\end{array}$ \\
\hline Bolts/year/machine & 29130 & 21400 & 17300 & 20000 & 20000 & 10300 & 19300 \\
\hline Bolt length & $\begin{array}{c}2.4 \mathrm{~m} \\
\text { With screen }\end{array}$ & $2.7 \mathrm{~m}$ & $2.7 \mathrm{~m}$ & $\begin{array}{c}2.4 \mathrm{~m} \\
\text { With screen }\end{array}$ & $\begin{array}{c}2.4 \mathrm{~m} \\
\text { With screen }\end{array}$ & $\begin{array}{c}3.0 \mathrm{~m} \\
\text { With and without screen }\end{array}$ & $\begin{array}{c}3.0 \mathrm{~m} \\
\text { With screen }\end{array}$ \\
\hline Shift/week & 12 & 11 & 16 & & & 12 & 11 \\
\hline Hours/shift & 9.08 & 9.27 & 8.03 & 10.5 & 10.5 & 8.8 & 9.45 \\
\hline
\end{tabular}

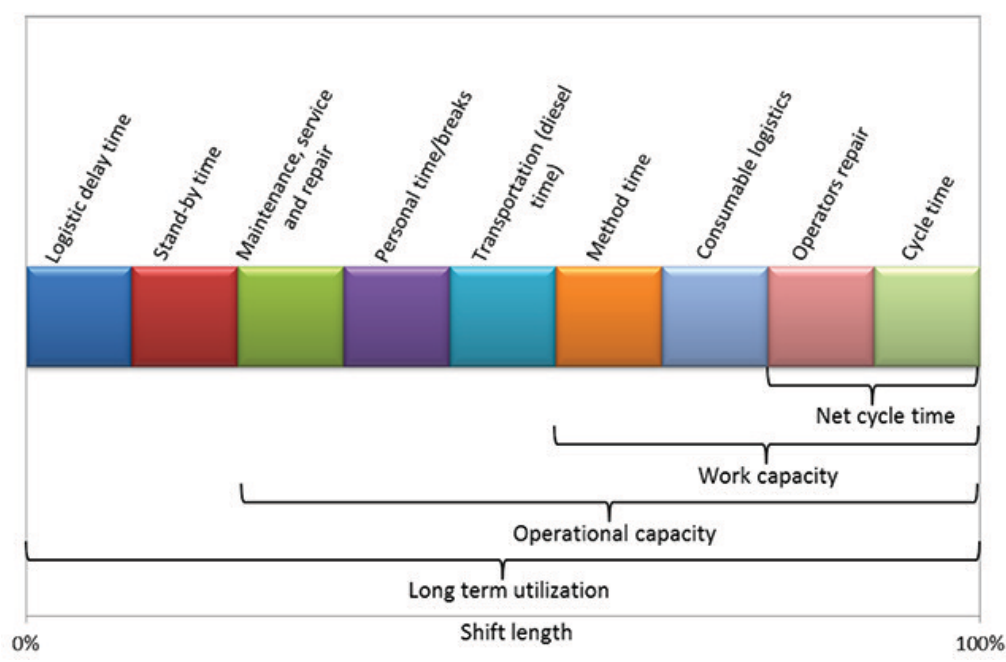

Figure 4-Suggested capacity definitions for bolting

mines and the equipment's actual performance level. Therefore, a productivity definition has been suggested by the project behind this research (MIGS WP-11). The definition is based on the analysis of data from the mining companies and on discussions with the mining companies and their suppliers. The proposed definition is shown in Figure 4 and described below.

\section{Net cycle time}

The net cycle time for bolting is defined as the net time for drilling one hole and installing one bolt. No additional time is included; it describes only the pure, undisturbed bolt installation time.

\section{Work capacity}

In addition to net cycle time, other time-consuming activities at the face are included in work capacity. Method time includes support activities such as collecting and installing raw material and elements for the bolting process (concrete, bolts, screen etc.). Operator repair includes all repairs 


\section{Productivity of rock reinforcement: methodology development}

performed by the operator at the face. Many mines keep track of work capacity by having the operator report the time when the bolting equipment is moved to the area and when it is removed from the area.

\section{Operational capacity}

Other necessary activities not occurring at the face are included in operational capacity, in addition to work capacity, such as transportation of the rig between different faces, personal time and breaks for the operator, maintenance, service and repairs in the workshop.

\section{Long-term utilization}

Long-term utilization describes the achieved capacity over longer periods (months, years). This capacity measure is affected by the logistic delay time for personnel, as this structurally reduces the effective shift time. Standby time measures the time when the equipment is available but not used. For sequential operation, this may be significant, but it can be controlled and reduced by management control.

\section{Time intervals}

The time intervals for capacity calculations vary between organizations. They can be measured in installed bolts per hour, shift, week, month, or year. Since the number of working hours per shift, week, month, and year varies across operations, using capacities per hour is recommended when comparing different techniques and operations.

On a management level and for decisions on investments in new equipment, the number of installed bolts per year is normally used. Therefore, this parameter is included, even if it varies depending on shift forms and other site-specific conditions.

\section{Results and discussion}

The large variations in rock mass characteristics across the case study mines will naturally influence the rock support productivity of each mine. Drilling is faster in weak ground, insertion of bolts or grouting material can sometimes be difficult in broken or fractured ground etc.

The ground support efficiency was calculated using Equations [1]-[3], with results presented in Table IV. The table shows differences between the support systems in terms of face efficiency. Total time spent at the face is $49.6 \%$, on average, for manual bolting and $38.6 \%$, on average, for mechanized bolting. The total time spent on bolting is, on average, $26.8 \%$ for the manual rigs and $17.3 \%$ for the mechanized bolt rigs.

The main argument for manual installation of bolts in the Canadian mines is that this method is more efficient, with higher productivity. The findings of this study, however, do not confirm this assumption. In fact, in most cases, mechanized bolt installation shows higher productivity. Findings suggest that the net bolt installation time significantly decreases with the use of mechanized equipment, while work capacity and long-term utilization increase.

Based on the definitions given previously, the net cycle time, work capacity, and long-term capacity were calculated for the eight mines. The different support elements and bolt types (resin/plastic, concrete, and Swellex) vary significantly in their productivity, as shown in Table V. The net installation time (cycle time) is the shortest for Swellex but does not vary significantly between cement-grouted bolts and resin-grouted bolts. The Swellex installation, however, consists of only two activities, hole drilling and installation of the bolt, thus reducing the net installation time (cycle time). Furthermore, the installation does not involve any additional substances (concrete, resin cartridges etc.), further simplifying the procedures and reducing the maintenance.

In general, installation of concrete-grouted bolts has lower productivity, primarily due to the necessary cleaning procedures during and at the end of the shift. The maintenance is also more extensive, particularly because of the cement distribution system. Cement is mixed in batches, and the operators hesitate to mix a new batch close to the end of the shift. In contrast, the resin bolt is installed individually using cartridges; therefore, it does not have the drawback of working in batches. This leads to a more efficiently used shift, especially at the end. Nor are extensive cleaning procedures required.

A comparison of the long-term utilization (Table VI) shows that the resin has $43 \%$ higher capacity (long-term utilization) than cement-grouted bolts. The Swellex system

Table IV

Ground support efficiency

\begin{tabular}{|l|c|c|c|c|c|c|c|}
\hline & $\begin{array}{c}\text { Expanding } \\
\text { friction bolts } \\
\text { (Swellex) } \\
\text { Mine 8* }\end{array}$ & $\begin{array}{c}\text { Resin- } \\
\text { grouted } \\
\text { bolts } \\
\text { Mine 3 }\end{array}$ & $\begin{array}{c}\text { Cement- } \\
\text { grouted } \\
\text { bolts } \\
\text { Mine 1 }\end{array}$ & $\begin{array}{c}\text { Resin- } \\
\text { grouted } \\
\text { bolts } \\
\text { Mine 6** }\end{array}$ & $\begin{array}{c}\text { Resin- } \\
\text { grouted } \\
\text { bolts } \\
\text { Mine } 7^{* *}\end{array}$ & $\begin{array}{c}\text { Cement- } \\
\text { grouted } \\
\text { bolts Mine 5 } \\
\text { (in-house) }\end{array}$ & $\begin{array}{c}\text { Cement- } \\
\text { grouted } \\
\text { bolts Mine 5 } \\
\text { (contractor)* }\end{array}$ \\
\hline (1) Total time at the face (\%) & 35.6 & 44.5 & 23.2 & 46.1 & 53.2 & 38.6 & 51.0 \\
(2) Total time bolting (\%) & 19.0 & 23.3 & 13.4 & 23.7 & 29.8 & 10.6 & 20.3 \\
(3) Face efficiency (\%) & 53.3 & 52.4 & 57.9 & 51.5 & 56.0 & 27.5 & 39.7 \\
\hline
\end{tabular}

${ }^{*}$ Mechanized bolting ** Manual bolting 


\section{Productivity of rock reinforcement: methodology development}

\begin{tabular}{|c|c|c|c|c|c|c|c|}
\hline \multicolumn{8}{|l|}{$\begin{array}{l}\text { Table } V \\
\text { Productivity measures }\end{array}$} \\
\hline & $\begin{array}{c}\text { Expanding } \\
\text { friction bolts } \\
\text { (Swellex) } \\
\text { Mine } 8^{\star}\end{array}$ & $\begin{array}{c}\text { Resin- } \\
\text { grouted } \\
\text { bolts } \\
\text { Mine } 3\end{array}$ & $\begin{array}{c}\text { Cement- } \\
\text { grouted } \\
\text { bolts } \\
\text { Mine } 1^{\star *}\end{array}$ & $\begin{array}{c}\text { Resin- } \\
\text { grouted } \\
\text { bolts } \\
\text { Mine } 6\end{array}$ & $\begin{array}{c}\text { Resin- } \\
\text { grouted } \\
\text { bolts } \\
\text { Mine } 7\end{array}$ & $\begin{array}{l}\text { Cement- } \\
\text { grouted } \\
\text { bolts Mine } 5 \\
\text { (in-house) }\end{array}$ & $\begin{array}{c}\text { Cement- } \\
\text { grouted } \\
\text { bolts Mine } 5 \\
\text { (contractor) }\end{array}$ \\
\hline Net cycle time (bolts/hour) & 30 & $17.6-20.6$ & 19.5 & 15.3 & 13.6 & & \\
\hline Work capacity (bolts/hour) & $13-19$ & 10 & 11.3 & 7.88 & 7.61 & $4.15-6.57$ & $7.27-8.21$ \\
\hline Long-term utilization (bolts/hour) & 5.69 & 4.45 & 2.62 & 3.63 & 4.05 & 2.07 & 3.95 \\
\hline Number of bolts/year & 29130 & 21400 & 17300 & 20000 & 20000 & 10300 & 19300 \\
\hline
\end{tabular}

*Optimized maintenance, ${ }^{* *}$ complicated logistics

Table VI

\section{Long-term utilization}

\begin{tabular}{|l|c|c|}
\hline Bolt type & $\begin{array}{c}\text { Long-term utilization } \\
\text { (bolts/hour) }\end{array}$ & $\begin{array}{c}\text { Difference in long-term } \\
\text { utilization (\%) }\end{array}$ \\
\hline Swellex & 5.69 & 97 \\
Resin-grouted bolts & 4.04 & 43 \\
Cement-grouted bolts & 2.88 & 0 \\
\hline
\end{tabular}

has advantages similar to those of the resin bolts, with an even shorter installation time. For the mines in the study, the Swellex system has $97 \%$ higher capacity (long-term utilization) than cement-grouted bolts. This variation is significant and should be considered when selecting support elements.

Even though Swellex systems have significantly higher productivity, the use of Swellex depends to a large extent on the prevalence of corrosion. In the studied mines, the arguments for/against Swellex are related to corrosion, but various kinds of corrosion protection, such as plastic coating, can be employed. Furthermore, all bolts are affected by corrosion, albeit in different forms. Severe corrosion may occur because of inadequate installation of grouted bolts or as a result of rock movements, sometimes enhanced by galvanic currents.

It is often difficult to see a clear advantage of cementgrouted over resin-grouted bolts. Some say cement is less costly, but this relates to the direct cost. If increased maintenance and lower overall productivity are also considered, the cost benefit may change. Others argue it is possible to change the amount of cement (the recipe) if, for example, the rock is more fractured, but such changes or modifications have not been reported by individual operators. The cement system causes additional problems, given the significant time required for cleaning and the increased maintenance time, both of which reduce the total operational capacity.
For resin-grouted bolts, there can be individual variations in the total number of cartridges and in the relationships between fast- and slow-hardening cartridges in each hole. One alternative is to use a two-component, pumpable resin, where only the required amount of resin is mixed. This is now available and used in Canada and Australia.

Figure 5 presents the time distribution for bolting for Mine 1 following the productivity measures suggested. For a mechanized bolt rig, the actual bolt cycle time represents $13 \%$ of the total shift time, while $20 \%$ of the total shift time is taken up by maintenance and repair. In other words, maintenance and service are a very important part of the overall productivity. Since the rig is idle due to logistic delays about $32 \%$ of the total shift time, it is possible to increase productivity by reducing these delays.

\section{Conclusions}

In this paper we have sought a way of comparing the productivity of different ground support systems in different mines even if the prerequisites for the mines are different. The major findings are as follows.

> The proposed model for evaluating productivity can handle different equipment and input data, thereby allowing comparisons between the productivity of mines and equipment regardless of the prerequisites. However, it can sometimes be difficult to calculate all productivity measures due to lack of data

> The mining method greatly influences bolting productivity; in addition, the decision to optimize the face or the machine will give different productivity results. The proposed model has successfully been used here

> Productivity issues are important for any change of technology. The argument that manual installation is faster is widespread, but has not been substantiated by this study. In fact, the net bolt installation time is significantly shorter, the work capacity is higher, and the long-term utilization is also higher for mechanized equipment 


\section{Productivity of rock reinforcement: methodology development}

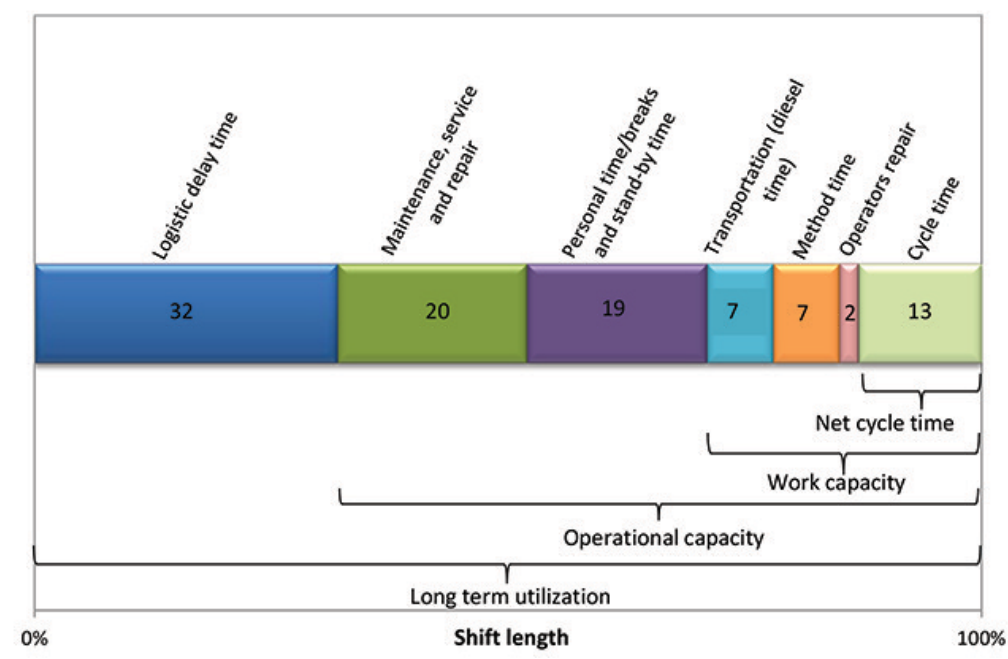

Figure 5-The suggested classification applied to Mine 1

> The results clearly show a difference between different bolt types. Resin-grouted bolts have $43 \%$ higher longterm utilization than cement-grouted bolts, and friction-anchored bolts have $97 \%$ higher long-term utilization than cement-grouted bolts

> Due to both safety and productivity reasons, it is concluded that mechanized bolting equipment is preferable to manual bolt installation. Most bolts are installed using Swellex, but other factors, such as corrosion and rock type need to be considered when choosing the bolt type.

\section{Acknowledgement}

The authors would like to acknowledge the project sponsor 'RTC-Mining Initiative on Ground Support Systems and Equipment' (RTC-MIGS), as well as the reference group, for all input and participation during discussions and workshops.

\section{References}

ATLAS CoPco. 2015. Safe rock with Boltec. http://www.youtube.com/ watch?v=05pGsen90qk [Accessed August 2015].

BAWDEN, F.W. 2011. Ground control using cable and rock bolting. SME Mining Engineering Handbook, 3rd edn. Vol. 1. Darling, P. (ed.). Society for Mining, Metallurgy and Exploration, Littleton, Co. pp. 611-625.

Clarc, D.A. And Filipowski, A. 1984. In-situ investigatrion of the correlation between underground roadway stability and roof support intensity. National Conference Publication - Institution of Engineers, Australia, vol. 84, no. 8. pp. 176-180.

Hadjigeorgiou, J. and Potvin, Y. 2011. Hard-rock ground control with steel mesh and shotcrete. SME Mining Engineering Handbook, 3rd edn. Vol. 1.
Darling, P. (ed.). Society for Mining, Metallurgy and Exploration, Littleton, CO. pp. 573-594.

HoEK, E., KaIser, P.K., and Bawden, F.W. 1995. Support of Underground Excavations in Hard Rock. Balkema, Rotterdam.

Новк, E. and Wood, F.D. 1987. Support in underground hard rock mines. Underground Support Systems. Udd, J. (ed.). Special Volume 35. Canadian Institute of Mining and Metallurgy, Montreal. pp. -6.

JaLIFAR, H., AzIZ, N., and HAdI, M.N.S. 2004. Non-linear analysis of bolt-groutconcrete interaction in reinforced shear joint. Journal of Mines, Metals and Fuels, vol. 52, no. 9-10. pp. 208-216.

LI, C.C and HÅkansson, U. 1999. Performance of the Swellex bolt in hard and soft rocks. Rock Support and Reinforcement Practice in Mining: Proceedings of the International Symposium on Ground Support Kalgoorlie, Western Australia, 15-17 March. Villaescusa, E., Windsor, C.R., and Thomson, A.G. (eds). Balkema, Rotterdam.

LI, C.C. 2007. A practical problem with threaded rebar bolts in reinforcing largely deformed rock masses. International Journal of Rock Mechanics and Rock Engineering, vol. 40, no. 5. pp. 519-524.

LI, C.C. 2010. A new energy-absorbing bolt for rock support in high stress rock masses. International Journal of Rock Mechanics and Rock Engineering, vol. 47. pp. 396-404.

MorLand, R.L. and Thompson, J. 1985. Developments in ground support practices at ISA mine. Symposium Series vol. 42. Australasian Institute of Mining and Metallurgy, Melbourne. pp. 131-135.

NMV. 2015. Kiruna bolt or NMX bolt by Nyberg Mekaniska Verkstad AB. http://www.nybergsmek.se [Accessed August 2015].

RafFoux, J.F. and DejeAn, M.J. 1980. Rockbolting and time-dependent behaviour of strata. Transactions of the Institute of Mining and Metallurgy, Section A: Mining Technology, vol. 89. pp. 41-47. 